\title{
EKSPLORASI FENOMENA KORBAN BULLYING PADA KESEHATAN JIWA REMAJA DI PESANTREN
}

\author{
Athi' Linda Yani ${ }^{1}$, Indah Winarni ${ }^{2}$, Retno Lestari ${ }^{3}$ \\ ${ }^{1}$ FIK UNIPDU Jombang \\ ${ }^{2,3}$ Fakultas Kedokteran Universitas Brawijaya
}

\begin{abstract}
ABSTRAK
Bullying yang terjadi di Indonesia banyak ditemukan di lingkungan sekolah baik formal maupun non formal. Menurut penelitian terdahulu kasus bullying yang sering terjadi sekitar $61-73 \%$ dalam bentuk kekerasan, pemerasan, mengancam dan mengambil barang-barang, selebihnya merupakan kasus bullying dalam bentuk yang lain seperti cyber bullying. Penelitian ini bertujuan untuk menggali pengalaman santri yang menjadi korban bullying di pesantren. Tujuan khusus dari penelitian ini untuk mengeksplorasi pengalaman santri yang menjadi korban bullying di pesantren, mengeksplorasi kondisi yang dialami santri saat mendapat perilaku bullying di pesantren, mengeksplorasi perasaan santri saat mengalami bullying di pesantren, mengeksplorasi tindakan yang dilakukan santri saat mengalami bullying di pesantren. Metode yang digunakan dengan menggunakan desain kualitatif pendekatan fenomenologi interpretif. Lokasi penelitian di salah satu pesantren yang ada di Jombang. Teknik pengambilan data melalui wawancara mendalam dengan waktu 20-30 menit menggunakan alat perekam. Partisipan dalam penelitian ini adalah santri yang mengalami perilaku bullying di salah satu pesantren di Jombang. Pemilihan partisipan sebagai narasumber dengan teknik purposive sampling. Jumlah partisipan dalam penelitian sebanyak 5 orang yang pernah mengalami bullying di pesantren. Hasil dan analisis didapatkan delapan tema yaitu pertentangan, mengganggu, mendapat perilaku yang menyakitkan dari senoir, merasa tertekan, kehilangan motivasi, berusaha mengamankan diri, mencari pertolongan dan tidak menyelesaikan masalah. Penjelasan dari tematema diatas merupakan proses perjalanan panjang dari pengalaman korban yang mengalami bullying di pesantren sehingga menghasilkan sebuah tema besar terjebak dalam sebagian tradisi pesantren yang melemahkan semangat.
\end{abstract}

Kata Kunci : Bullying, Kesehatan jiwa, Pesantren, Remaja

\begin{abstract}
Bullying happens in Indonesia majority found in the school environment, both formal and non-formal. In non-formal school also there were many cases of bullying. According to previous researchers around 61-73\% of bullying happens in form of violence, extortion, threatening, stole and case of bullying in other forms such as cyber bullying. The aim of the research generally to explore meaning of students experience who are victims of bullying at islamic boarding school, then specific aim explore understanding of students against bullying, exploring the conditions that experiencedby students for being bullied, explores feelings of students who experience bullying at islamic boarding schools and explore actions of student for bullying behaviors at islamic boarding schools. The method used qualitative design with an interpretive phenomenological approach to find phenomenon of teenage experience. Location in one of islamic boarding schools in Jombang. A number of participants were 5 students who have experienced bullying islamic boarding schools. Data collection techniques through in-depth interviews during 20-30 minutes and used voice recorder. Results and analysis obtained eight themes, namely opposition that never ended, intrusive, got behavioral painful of senior at junior, felt depressed, demotivated, trying to secure themselves, seeking help and not solve the problem. Explanation of themes long journey from an experience of victims who suffered bullying in islamic boarding schools so direct to a major theme stuck in most islamic boarding schools tradition that stultifying.
\end{abstract}

Keyword : Bullying, Mental Health, Islamic Boarding school

Jurnal IImu Keperawatan, Vol:4, No.2 ; Korespondensi : Athi' Linda Yani.Prodi S1 Keperawatan FIK UNIPDU Jombang. Alamat : FIK UNIPDU Tromol Pos 10 Peterongan Jombang. Email : athilindayani@fik.unipdu.ac.id, lindayani1987@gmail.com,no. Hp: 085649336469 


\section{PENDAHULUAN}

Bullying merupakan tindakan kekerasan yang dilakukan secara berulang dan melibatkan adanya kekuatan fisik antara korban dan pelaku. Di Indonesia, Komisi Perlindungan Anak Indonesia (KPAl) merilis data bahwa kasus bullying ditemukan sekitar 87,6 \% dimana korban laki-laki lebih banyak dari perempuan dan perilaku bullying lebih rentan terjadi pada usia remaja awal (Desiree, 2013 ; Aisiyai, 2015).

Bullying yang terjadi di Indonesia banyak ditemukan di lingkungan sekolah baik formal maupun non formal. Menurut penelitian terdahulu kasus bullying yang sering terjadi sekitar 61 - 73 \% dalam bentuk kekerasan, pemerasan, mengancam dan mengambil barang-barang, selebihnya merupakan kasus bullying dalam bentuk yang lain seperti cyber bullying

Berdasarkan studi fenomenologi menurut Ndetei et al. (2007), perilaku bullying juga terjadi di sekolah menengah dengan melakukan wawancara dari beberapa siswa menyatakan bahwa bentuk bullying yang banyak terjadi dengan memukul, mengejek, memanggil nama panggilan, mengancam, mengambil barang milik korban. Perilaku tersebut dilakukan secara berulang-ulang dan berkelanjutan. Keadaan ini akan terus berlangsung karena korban tidak berani untuk melawan. Dampak dari perilaku bullying dapat menyebabkan korban merasa malu, tertekan, perasaan takut, sedih dan cemas. Jika kondisi ini berkepanjangan bisa mengarah ke depresi (Okoth, 2014).

Selain dampak dari masalah psikologis juga dapat berpengaruh terhadap masalah kesehatan fisik seperti memar pada daerah yang dipukul, lecet, bengkak, sulit tidur, nafsu makan menurun. Gejala lain yang dimunculkan diantaranya merasa terancam, sulit berkonsentrasi, penurunan prestasi akademik dan merasa sendiri (Laeheem, 2013).

Kasus bullying yang baru-baru ini terjadi oleh seorang santri disalah satu pondok pesantren hingga berujung meninggalnya seorang santri. Para pelaku membawa korban yang masih duduk di bangku SMP ke dalam sebuah kamar dan mematikan lampunya. Didalam kamar tersebut korban dihajar beramai-ramai hingga pukul 23.00 WIB. Setelah itu dilarikan ke rumah sakit. Dan keesokan harinya korban meninggal dunia (Sindonew.com, 2016).

Berdasarkan studi pendahuluan yang dilakukan oleh peneliti pada tanggal 6 Februari 2016 disalah satu lingkungan pesantren Jombang diperoleh data bahwa kejadian bullying terjadi pada siswanya. Pesantren merupakan lingkungan yang mempunyai rutinitas kegiatan antara senior 
dan junior. Selain itu karakteristik lingkungan pesantren yang memiliki jumlah santri yang cukup banyak. Santri datang dari berbagai daerah yang memiliki perbedaan latar belakang budaya. Jumlah pembina santri dengan banyaknya santri yang tinggal di pesantren tidak seimbang. Letak bangunan komplek antara santri lama dengan yang baru tidak dipisahkan. Santri yang tinggal di pesantren tidak semua atas keinginan pribadi melainkan karena paksaan dari orang tua. Sehingga hal ini yang menjadi pemicu terjadinya bullying. Korban bullying mengaku bahwa ada rasa ketakutan, terancam, merasa tidak aman, sehingga hal ini mempengaruhi mental siswa selama berada di lingkungan tersebut. Dampak lanjut dari kejadian bullying pada siswa tidak mau masuk sekolah dan memutuskan untuk tidak melanjutkan sekolah.

Bullying sering terjadi di lingkungan pesantren dari pada lingkungan umum. Bullying di pesantren kebanyakan disebabkan oleh beberapa hal diantaranya mereka yang jauh dari pengawasan orang tua, berasal dari berbagai daerah yang memiliki adat dan budaya yang berbeda. Selain itu kurangnya pengawasan dari pihak pesantren serta banyaknya aturan-aturan yang ditetapkan. Tujuan dibentuknya aturan di pesantren yaitu untuk meningkatkan kedisiplinan para santri namun hal itu justru dianggap sebagai pengekang. Siswa yang tinggal di pesantren umumnya bukan atas dasar kemauan dan kesadaran sendiri melainkan atas keinginan orang tua karena kesibukannya sebagian besar orang tua merasa tidak sanggup mengontrol dan mengurus anak. Sehingga pesantren dianggap lingkungan yang tepat untuk dapat memberikan kontrol dan perhatian pada putra putri mereka (Desiree, 2013).

Dampak negatif dari perilaku bullying dapat mempengaruhi segala aspek kehidupan (psikologis, fisik maupun sosial) yang akan terus mempengaruhi perkembangan selanjutnya. Sehingga penting bagi perawat untuk mencegah dan menanggulangi perilaku bullying. Hal ini erat kaitannya dengan peran dan fungsi perawat dalam upaya pelayanan kesehatan utama (Primary Health Care) yang berfokus pada upaya promotif dan preventif terkait pengetahuan dan cara pengendalian prilaku bullying serta mencegah dampak terhadap masalah kesehatan (Stuart, 2016).

\section{METODE}

Penelitian ini ingin menggali makna pengalaman santri yang menjadi korban bullying di lingkungan pesantren menggunakan desain kualitatif dengan pendekatan fenomenologi interpretif yang menjadi ciri khas dari metode ini adalah menginterprestasikan, memaknai, dan 
memahami lebih detail terhadap fenomena yang terjadi (Polit \& Beck, 2010).

Lokasi penelitian terletak di salah satu Pondok Pesantren yang ada di Jombang, Waktu pelaksanaan penelitian dilakukan pada bulan 5 April 2016, proses pengambilan data dilakukan di sekolah yang lokasinya berada di dalam komplek pesantren dan pemilihan partisipan sebagai narasumber dengan teknik purposive sampling. Jumlah partisipan pada penelitian ini sebanyak 5 orang. Teknik pengumpulan data pada penelitian ini dengan menggunakan wawancara mendalam. setelah data terkumpul kemudian dianalisis dengan menggunakan langkah dari Van Manen dengan pendekatan holistik, selektif dan rinci.

\section{HASIL}

Penelitian ini menghasilkan tujuh tema berdasarkan analisis tematik dengan pengumpulan data, membaca transkip wawancara, pemilihan kata kunci dari kalimat partisipan, mencari tema penelitian dengan melalui penentuan kategori menjadi sub-sub tema, dari pengelompokan sub-sub tema yang sejenis akan membentuk sub tema yang akan membentuk tema penelitian. delapan tema yang dihasilkan menggambarkan fenomena bullying yang terjadi di pesantren yaiyu ; (1) bullying dipahami sebagai pertentangan yang tidak pernah usai, (2) bullying dipahami sebagai tindakan mengganggu, (3) partisipan mendapat perilaku yang menyakitkan dari senior kepada junior, (4) partisipan merasa tertekan, (5) partisipan merasa kehilangan motivasi, (6) partisipan berusaha mengamankan diri, (7) mencari pertolongan, (8) tidak menyelesaikan masalah.

\section{Tema 1 : Bullying dipahami sebagai pertentangan yang tidak pernah usai}

Pemahaman partisipan yang menyadari bahwa penyebab bullying karena adanya pertentangan yang tidak pernah usai. Tema pertentangan yang tidak pernah usai mengandung arti adanya perlawanan dari pihak lain yang tidak pernah berakhir disertai dengan melakukan ancaman atau kekerasan. Kondisi ini terjadi karena adanya perselisihan antara pelaku dan korban. Tema ini dibangun dari sub tema perasaan tersaingi, ketegangan dan dinilai perbuatan yang tidak benar.

Sub tema perasaan tersaingi memiliki arti keadaan yang membuat takut kalah, tidak suka dengan keadaan orang lain yang dapat melebihinya.

" mereka bilang benci dengan saya karena setiap ada tugas kelompok, saya disuruh ngerjakan sendiri tapi saya gak bisa, trus saya dibilang gitu aja gak pecus..kamu itu bodoh, trus dia bilang rugi punya kelompok kaya kamu, sana kamu pergi jangan ikut kelompok kita.. "(p1) 
" mereka biasanya iri sama saya, kan biasanya saya suka dibelain pembina karena saya gak ngapa-ngapain disalahkan terus sama mereka..terkadang juga saya sering diajak pembina keluar cari buku, nah merekanya iri sama saya.."(p5)

Makna pernyataan di atas partisipan memiliki kemampuan lain di bidang tarik suara sehingga sering diikutkan dalam setiap kegiatan perlombaan, keadaan ini yang juga membuat pelaku iri dan membencinya.

Sub tema kedua adalah ketegangan adalah suatu kondisi yang tidak sesuai dan dinilai tidak tepat oleh pelaku, yang termasuk di dalamnya yaitu karena ketidakcocokan dan perbedaan pendapat.

" gara-gara pas selesai ulangan tengah semester saya gak mau nyontekin dia.."(p1)

"..ya, dikira wajah saya ngece (menghina), padahal saya gak menghina..kan waktu itu saya tertawa sama teman sebelah saya.."(p2)

"ya gak tau, kadang salah sedikit sudah dipermasalahakan, misalnya saya salah sebut atau ngomong itu sudah dipikir ngatain dia.."(p3)

Pernyataan partisipan diatas menyatakan bahwa ketika ulangan harus jujur dan tidak mau melakukan perbuatan curang, prinsip yang dipegang dianggap pelaku sebagai bentuk alasan untuk tidak memberikan contekan.

Sub tema ketiga tidak benar memiliki arti tindakan negatif yang dapat merugikan orang lain sehingga hal tersebut tidak baik untuk dilakukan.

“..salah bu kalau ketauan pasti mereka kena sangsi..lagian kaya gitu kan gak baik bu suka bikin sengsara orang lain.."(p1)

Pernyataan dari kedua partisipan menyadari bahwa perbuatan yang dilakukan seperti mengganggu, menyakiti orang lain merupakan tindakan yang salah. Perbuatan untuk menyakiti orang lain juga disadari telah melanggar aturan tata tertib yang ada dipesantren.

\section{Tema 2 : Bullying dipahami sebagai tindakan} mengganggu

Mengganggu merupakan tindakan yang dilakukan pelaku untuk mengusik dan membuat kekacauan sehingga dapat merisaukan hati, membuat perasaan tidak nyaman dan juga dapat merugikan korban. Tema ini dibangun dari sub tema tindakan sewenang-wenang untuk menyakiti secara fisik dan psikis.

Sub tema tindakan sewenang-wenang untuk menyakiti secara fisik dan psikis memiliki makna bahwa pelaku memiliki kekuasaan 
untuk melakukan tindakan semaunya sendiri, tanpa memperhatikan perasaan orang lain, menyakiti korban baik secara fisik maupun psikisnya.

" itu loh yang biasanya suka nertawain, main kekerasan, biasanya mereka itu sering bilang awas kamu kalau gak nurut tak pukul, ya kaya dikroyok gitu. Kan padahal anaknya diem aja tapi dianya suka terus-terusan gangguin sampai buat anaknya nangis, tapi kalau sudah nangis mereka ketawa-ketawa sambil ngata-ngatain cengeng (nangisan) huuu dasar anak mama..."(p1)

Makna dari pernyataan diatas menunjukan bahwa pelaku dengan leluasa melakukan tindakan dengan sengaja membuat korban menderita tanpa memperdulikan perasaan orang lain seperti melakukan kekerasan fisik, memberikan ancaman dengan menggunakan kekuasaan yang dimiliki untuk menindas korbannya.

\section{Tema 3 : Mendapat perilaku yang} menyakitkan dari senior pada junior

Tema diatas memiliki makna bahwa tindakan yang diterima korban dari pelaku dengan sengaja untuk melukai baik secara fisik maupun psikisnya. Tema ini dibangun dari beberapa sub tema diantaranya : mengalami kekerasan fisik, dijatuhkan mentalnya dan mendapat tekanan batin.

Sub tema pertama mengalami kekerasan fisik yang memiliki arti merasakan, menanggung tindakan yang dilakukan pelaku sehingga menimbulkan kerusakan fisik. Korban merasakan atau mengalami penderitaan secara fisik

" main kekerasan, pertamanya kan saya diem tiba-tiba saya ditendang, trus saya berusaha balik nendang, setelah itu saya dibawa keluar trus saya dicekik sampai jatuh bu.."(p1)

Pernyataan dari partisipan diatas menyatakan bahwa korban sering mendapat perilaku kekerasan fisik dari pelaku selama berada dipesantren. Tanpa ada masalah yang jelas penyebab korban dianiaya.

Sub tema kedua dijatuhkan mental memiliki makna dengan sengaja pelaku melakukan tindakan untuk membuat lawan merasa tidak percaya diri, rendah diri, perasaan takut, keragu-raguan, salah tingkah dan lemah. Tindakan yang dilakukan pelaku dengan menggertak, memojokan dan merendahkan.

" saya ke pasar pas waktu liburan sekolah dan ketemu sama mas-mas, saya ngobrol bentar sama masnya karena saya mau tanya rombongan pulang bu..eh sesampai di pondok 
didatengin sama mbak-mbaknya dan

dilabrak.."(p5)

Partisipan tersebut menyatakan bahwa perilaku mereka dengan melabrak membuat korban rendah diri dan lemah, pelaku lebih dari satu orang mendatangi korban dan memarahi di depan umum tanpa menanyakan kejadian yang sebenarnya.

Sub tema ketiga tekanan batin sendiri memiliki makna situasi ketika perasaan seseorang sudah tidak sanggup lagi menerima hal-hal buruk yang diterimanya dan keadaan itu membuat jiwa seseorang terguncang.

" ya sangat sedih, saat itu saya antri ambil makan bu, trus saya didorong dari belakang, nasi saya sampai tumpah dan saya ambil nasi lagi eh langsug disela tempatnya.."(p1)

Pernyataan partisipan diatas menyatakan bahwa kondisi yang dialami korban merasa sangat tertekan karena sikap pelaku yang selalu membuat korban menderita. Korban merasa sedih dan tidak berani melawan terkait tindakan yang dilakukan pelaku untuk menekan korban. Hal itu yang membuat korban tidak betah tinggal dipondok.

\section{Tema 4 : Merasa Tertekan}

Tema merasa tertekan memiliki arti situasi yang dialami sewaktu menghadapi keadaan yang tertindas, situasi ketika perasaan seseorang sudah tidak sanggup lagi menerima hal-hal buruk yang diterimanya, merasakan ketidaknyamanan dengan kondisi yang diterima korban sehingga membuat tidak bahagia. Tema ini dibangun dari sub tema merasa terbebani.

Sub tema merasa terbebani memiliki arti suatu keadaan yang sangat berat, kondisi yang sangat sulit dialami seseorang.

"gak betah bu, pernah saya mau pindah kamar. Saya lapor koordinatornya, saya bilang pak..saya pingin pindah kamar karena saya terus-terusan dibully sama anak kamar, ," $(p 2)$

Pernyataan partisipan diatas menjelaskan korban mendapat perilakuan yang tidak meyenangkan. Tindakan yang dilakukan pelaku membuat korban merasa terancam sehingga korban meminta untuk pindah mencari tempat yang lebih aman.

\section{Tema 5 : Kehilangan Motivasi}

Tema kehilangan motivasi yang memiliki makna tidak ada dorongan atau keinginan dari diri baik secara sadar atau tidak sadar untuk melakukan suatu tindakan yang memiliki tujuan.

" ya sering gak masuk sekolah karena sakit tapi kalau malas belajar sih iya kadang-kadang, yang paling males itu mengikuti kegiatan kamar karena kalau ke kamar pasti diejek, dikata-katain 
yaudah dari pada gitu mending gak usah ikut pengajian kamar.."(p2)

Penjelasan dari partisipan diatas menyatakan bahwa korban selalu mendapat perilaku yang tidak menyenangkan dari teman-temannya dikamar, korban tidak mau mengikuti kegiatan kamar untuk menghindar dari para pelaku.

\section{Tema 6 : Berusaha Mengamankan Diri}

Tema berusaha mengamankan diri dapat diartikan sebagai bentuk upaya yang dilakukan korban untuk menyelamatkan diri dari bahaya yang mengancam. Tema ini dibangun dari sub tema yaitu mencegah agar tidak terjadi perilaku bullying berulang.

Sub tema yaitu mencegah agar tidak terjadi perilaku bullying memiliki arti bahwa cara yang dilakukan korban untuk mencegah agar tidak terjadi lagi tindakan bullying.

“..ya saya gak marah, saya mengalah aja dari pada saya gak bolehin nanti malah dipukul.."(p1)

Pernyataan dari tiga partisipan diatas menyatakan bahwa tindakan yang dilakukan merupakan cara untuk membuat aman agar tidak terjadi lagi perilaku bullying .

\section{Tema 7 : Mencari Pertolongan}

Usaha yang dilakukan agar dapat melepaskan diri dari bahaya agar dapat meringankan penderitaannya. Tema ini dibangun dari sub tema berusaha melaporkan memiliki makna berusaha melaporkan memiliki makna bahwa ada upaya yang dilakukan korban untuk memberitahukan kepada pihak lain agar mendapatkan bantuan.

" pernah sy telpon cerita mama, ya paling mama bilang..yaudah yang sabar aja itu menjadi tantangan kamu mondok cari ilmu..pasti ada tantangannya jadi sabar..kalu kamu digituin coba tanyain atau dideketin kenapa dia seperti itu sama kamu?yaudah pokonya sabar sama kuat aja.." (p4)

Partisipan berusaha mencari bantuan dengan cerita kepada orang tuannya. Berharap dengan bercerita orang lain dapat mengerti kondisi yang dialaminya sehingga mereka dapat pembelaan.

\section{Tema 8 : Tidak menyelesaikan masalah}

Tema tidak menyelesaikan masalah memiliki arti suatu kegiatan atau cara yang tidak dapat memecahkan persoalan, perbuatan yang tidak dapat menangani permasalahan yang muncul. Tema ini dibangun dari sub tema ketidak berdayaan.

Sub tema ketidak berdayaan memiliki arti bahwa sesorang sudah tidak mampu lagi untuk mengatasi masalah yang dialami, sudah tidak memiliki cara. Korban tidak dapat 
menghindar dari pelaku. Segala cara yang dilakukan korban untuk menjauhi pelaku agar tidak diganggu tidak dapat dihindarkan.

" pernah saya lari pas mau disuruh ngambilin bajunya ke bulek cuci, kan bajunya banyak banget saya gak kuat bawanya..eh besoknya pas ketemu saya didorong-dorong sambil ditanyain kenapa saya lari..kata dia " mau kamu tak tempeleng (tonjok).."(p3)

Korban kehabisan cara untuk menghindar dari bullying karena usaha untuk pernyataan partisipan di atas melarikan diri hanya dapat menghindar sementara dari pelaku, jika korban bertemu lagi dengan pelaku akan diganggu. Segala tindakan yang dilakukan tidak membuat korban terbebas dari ancaman pelaku malah justru semakin parah balasannya.

\section{PEMBAHASAN}

Bullying dipahamai karena adanya Pertentangan yang tidak pernah usai. Pernyataan Salleh (2014) dalam penelitiannya terkait perilaku bullying sering terjadi antar siswa karena hal sepele seperti kontak mata sinis, bicara kasar sehingga memicu terjadinya bullying seperti menghina, menjatuhkan yang menyebabkan perkelahinan antar siswa dari etnis yang berbeda (Salleh, 2014). Pendapat lain menyatakan bahwa bullying bermula dari konflik antar individu untuk merendahkan dengan mengatakan bodoh, pemalas. Keadaan tersebut disebabkan karena ada perasaan tidak senang dari pelaku, iri ketika melihat keberhasilan orang lain karena menganggap siswa yang berhasil sombong dan egois karena tidak mau memberi contekan (Wan, 2009 ; Sudan, 2014).

Berdasarkan penelitian sebelumnya bahwa adanya perasaan tersaingi karena keinginan yang tidak sesuai harapan atau sebab adanya ketidakcocokkan sehingga memicu ketegangan. Didukung penelitian terdahulu terkait bullying yang merupakan suatu tindakan dilakukan oleh dua pihak yang mengalami pertikaian dan ketidakseimbangan dalam hal kekuasaan, fisik, dan mental dilakukan secara berulang (Kim \& Thornton, 2009).

\section{Bullying dipahami sebagai tindakan mengganggu. Bullying merupakan perilaku} agresif yang didalamnya terdapat aspek kesengajaan untuk mendominasi, menyakiti, atau menyingkirkan, adanya ketidakseimbangan kekuatan baik secara fisik, usia, kemampuan kognitif, keterampilan, maupun status sosial. Tindakan ini dilakukan secara berulang-ulang oleh satu atau beberapa anak terhadap anak lain sehingga korban berada dalam keadaan tidak mampu mempertahankan diri secara efektif untuk melawan tindakan negative yang diterima 
(Black dan Jackson 2007 ; Omoniyi, 2013).

Penelitian lain menyatakan bahwa perilaku bullying yang biasa dilakukan oleh pelaku dengan menyakiti korban, mempermalukan dengan menghina korban didepan umum, berbicara kasar. Pelaku merasa senang melihat korban menangis dan tersakiti (Tumon, 2014; Salleh, 2014). Kondisi ini menyebabkan korban yang sering mengalami penindasan, dijatuhkan mentalnya banyak tercatat mengalami gangguan psikologis bahkan mengarah ke patologis (Malian, 2012 ; Rachel, 2014).

\section{Mendapat perilaku yang menyakitkan dari} senior pada junior. Hal ini ditunjang penelitian lain yang mendukung terkait perilaku bullying yang dilakukan secara fisik umumnya terjadi pada siswa menengah. Korban ditendang kemudian ditinju, sering kehilangan barangnya dan tidak hanya itu mereka mempermalukan korban dengan menaruh kertas sampah diatas kepalanya. Selain itu perilaku lain yang dapat menyebabkan korban dilakukan perawatan intensif dirumah sakit karena mengalami cidera pada tulang rusuk dan bahu akibat dipukuli. Kondisi tersebut dapat menyebabkan korban merasa takut, mengalami kondisi yang sangat terancam. Selain itu korban tidak berani berangkat sekolah, mengalami penurunan prestasi akademik. Penyerangan yang berulang ini akan dapat mempengaruhi rasa kepercayaan diri seseorang menjadi rendah (Aisiyai, 2015; Sudan, 2015).

Pernyataan partisipan lain bahwa korban mengalami perilaku bullying mental yaitu dengan sengaja pelaku melakukan tindakan untuk membuat lawan merasa tidak percaya diri, rendah diri, perasaan takut, keraguraguan, salah tingkah dan lemah. Tindakan tersebut dilakukan pelaku dengan menggertak, memojokkan dan merendahkan. Korban mengalami pemerasan secara paksa oleh pelaku, dan korban dipermalukan dengan dipaksa untuk melepas sarungnnya didepan umum agar ditertawakan banyak orang. Selain itu juga perilaku yang meyakiti perasaan korban sehingga membuat sedih, menangis, ketakutan dan tidak berani melawan terkait tindakan yang dilakukan pelaku untuk menekan korban. Korban merasa sangat kesal karena selalu dikatain dan dihina, hal itu yang membuat korban tidak betah tinggal dipondok.

Penelitian serupa yang menyatakan bahwa tindakan bullying dapat memberikan dampak negatif terhadap korban karena sering diganggu sehingga korban merasa cemas, takut, bahkan hilang kepercayaan diri, terluka, menderita dan tidak berani berangkat ke sekolah. Selain itu korban akan mengalami 
trauma yang berkepanjangan sampai dewasa nanti (Laeheem, \& Baka, 2011). Berdasarkan teori Bandura mengatakan bahwa perilaku manusia sebagian besar merupakan perilaku yang dipelajari. Demikian halnya dengan perilaku kekerasan. Teori ini menyatakan bahwa perilaku kekerasan merupakan perilaku yang dipelajari dari pengalaman masa lalu melalui pengamatan langsung (imitasi), pengukuhan positif, dan karena stimulus diskriminatif (Simbolon, 2012). Pernyataan tersebut menguatkan bahwa korban yang biasa dibully akan cenderung meniru untuk melakukan hal tersebut dan memiliki perilaku nakal (Stuart, 2016).

Penelitian lain juga berpendapat bahwa peran serta keluarga sangat berpengaruh terhadap perkembangan remaja dimasa depan, hal ini dibuktikan bahwa pelaku yang dulunya pernah mengalami bullying dan kekerasan dalam keluarga secara tidak langsung dipelajari sebagai bentuk pertahanan dirinya. Sedangkan observasi dan imitasi adalah proses pembelajaran utama dalam pertumbuhan remaja. Hal ini membuat seseorang yang mengalami frustasi dengan mudah mereka akan menyerang orang lain. Sebagai bentuk kekecewaan serta kemarahan mereka melampiaskan dengan perilaku menyerang dan perilaku bullying (Chiu, 2013).
Ditunjang dari penelitian lain bahwa salah satu alasan orang yang menjadi korban bullying dan mengamati secara langsung akan mengadopsi perilaku bullying. Korban bullying akan kehilangan kepercayaan diri dan harga dirinya rendah, untuk meningkatkan harga dirinya mereka menjadikan orang lain sebagai sasaran untuk balas dendam, mendominasi dan merasa kuat (Salleh \& Khalim, 2014). Hal ini juga dikaitkan dengan usia subjek yang berada di rentang 12 -15 tahun, pada usia ini remaja secara emosioanal lebih labil dan memiliki banyak konflik karena kecenderungan untuk memberontak dari segala aturan termasuk dari orang tuanya. Untuk melampiaskan kekesalannya anak cenderung menjadi pelaku bullying atau sebaliknya menyebabkan anak menjadi tertekan sehingga menjadi sasaran korban bullying (Tumon, 2014).

Perilaku bullying yang kerap terjadi diasrama dari penelitian terdahulu menyatakan bahwa pesantren merupakan lingkungan baru dibutuhkan waktu untuk proses transisi dari rumah. Pesantren merupakan tempat tinggal baru mereka untuk beradaptasi dengan para santri yang datang dari berbagai daerah yang membawa adat dan budaya masing-masing, sehingga sering terjadi kesalahpahaman. Selain itu mereka menghabiskan waktunya sebagaian besar berada dipesantren sehingga intensitas untuk berkomunikasi dan bertemu 
dengan senior lebih banyak keadaan tersebut yang memicu terjadinya bullying. Perilaku bullying yang sering terjadi dengan melempar barang ketempat orang lain , mengikat celana korban kekursi, menempel selembar kertas dengan kalimat yang bertulis Misalnya, "Silakan tendang saya; itu gratis. "pada orang yang ada dibelakangnya. Hal tersebut dilakukan ketika tidak ada pengawas diruangan (Herzt, 2013 ; Laeheem; 2013).

Penelitian lain menyatakan bahwa sistem pendidikan yang ketat dapat memicu terjadinya bullying, mereka merasa terkekang sehingga bentuk pelampiasannya dengan melakukan bullying pada temannya. Pelaku melakukan hal tersebut bertujuan untuk mendapat kepuasan dan kesenangan. Keadaan ini juga berkaitan dengan bagaimana orang tua memperlakukan korban selama dirumah dengan sikap yang otoriter dan memaksa anak untuk tinggal dipesantren. Umumnya mereka yang masuk pesantren tanpa ada kesadaran dalam dirinya sendiri pasti akan menolak dan sulit beradabtasi dengan aturan yang ada dipesantren seperti larangan membawa ponsel, tidak ada televisi, tidak boleh keluar tanpa ijin, harus mengikuti jadwal diniyah hal tersebut membuat mereka sangat tertekan sehingga melampiaskan dengan perilaku bullying (Desire, 2013 ; Omoniyi, 2013 ; Aisiya , 2014; Donoghoe, 2014).
Merasa tertekan, penelitian lain menyatakan bahwa siswa dipahamkan ketika mengalami bullying untuk segera mencari dukungan, menceritakan pada orang dewasa atau pihak sekolahan bahwa mereka menjadi korban bullying. Usaha yang mereka lakukan juga memiliki resiko yang sangat besar ketika hal tersebut diketahui oleh pelaku bullying karena akan berujung pada pembalasan. Bagi mereka yang berani menanggung resiko akan melakukan hal tersebut. Namun mereka kebanyakan takut dan tidak berani untuk bertindak, keadaan tersebut yang membuat mereka hanya bisa sabar dan pasrah dengan kondisi yang dialami (Donoghoe \& Almeida, 2014).

Kehilangan motivasi banyak penelitian lain yang mendukung bahwa bullying memiliki pengaruh besar terhadap kesehatan seseorang, korban akan merasakan cemas yang berkepanjangan sehingga dapat mengarah ke depresi. Tindakan untuk memojokkan, menyalahkan dan menertawakan akan membuat harga diri korban menjadi rendah. Selain itu korban merasa tidak nyaman dan tertekan, kondisi tersebut membuat korban tidak semangat untuk melakukan aktifitas dan jarang masuk kelas. Banyak korban yang mengalami kegagalan dalam akademik dan memutuskan untuk tidak melanjutkan sekolah. Kondisi tersebut dapat meningkatkan angka 
pengangguran sehingga semakin banyak kasus kenakalan pada remaja (Omoniyi, 2013 ; Nakou, 2014).

Berusaha mengamankan diri berdasarkan hasil penelitian menyatakan bahwa perilaku bullying dapat membuat korban merasa takut dan tidak berani melawan. Korban mendapat perlakuan kekerasan seperti ditendang, dipukul sampai terluka. Hal tersebut dilakukan berulang kali sampai membuat korban tidak mampu melawan, tidak ada usaha yang dapat dilakukan korban selain diam. Perilaku bullying membuat seseorang menjadi berpikir negatif pada diri sendiri, menganggap diri mereka bodoh dan tidak menarik, selain itu merasa diri mereka lemah sehingga tidak berani melawan dari serangan bullying (Chiu, 2013 ; Sudan, 2015).

Tidak menyelesaikan masalah penelitian yang mendukung terkait hal tersebut menyatakan bahwa korban yang menjadi target perilaku bullying akan terus berkelanjutan. Usaha yang dilakukan untuk menjauh dari kelompok pelaku bullying dengan menyendiri, selalu mengalah dan memilih untuk megambil antrian paling akhir ketika dipesantren. Korban dapat terlepas dari tindakan bullying kalau sudah melewati tahap ditahun pertama dan mereka dapat diterima oleh kelompok sebayanya (Rivers, 2009 ; Desire, 2013).

\section{KESIMPULAN}

Penelitian diatas menghasilkan 7 tema diantaranya ; bullying diapahami sebagai pertentangan yang tidak pernah usai, bullying diapahami sebagai tindakan mengganggu, partisipan mendapat perilaku yang menyakitkan dari senior kepada junior, partisipan merasa tertekan, partisipan merasa kehilangan motivasi, partisipan berusaha mengamankan diri, sia-sia menghindar.

Bullying terjadi tanpa ada maksud yang jelas atau dengan tujuan untuk menganggu korban yang dilakukan secara sengaja. Tindakan tersebut dapat menyakiti korban baik secara fisik maupun psikis sehingga dapat memberikan dampak negatif pada korban. Seperti adanya perasaan tertekan, takut, cemas, sedih dan membuat korban tidak nyaman serta kehilangan motivasi. Kondisi yang dialami korban secara berulang dapat berpengaruh terhadap kepercayaan diri, harga diri dan prestasi akademik.

Saran yang dapat diberikan adalah korban dapat bercerita atau melaporkan atas perilaku bullying yang dialami kepada pihak yang berwenang untuk mengatasinya. Mengusulkan dibentuknya UKS jiwa dipesantren dengan tujuan untuk mengembangkan kesehatan jiwa anak usia 
sekolah secara optimal sesuai dengan tahap perkembangannya. Penelitian selanjutnya perlu adanya penelitian tentang menggali makna pengalaman hidup pada santri yang menjadi pelaku bullying.

\section{DAFTAR PUSTAKA}

Aisiyai \& Ifeoma. (2015). Exploring bullying in nigerian secondary school and school administrators strategies for its' management department of educational administration and policy studies. Journal of Educational and Social Research, 5 (2) doi:10.5901/jesr.2015.v5n2p305

Black, S.A, \& jackshon, E . 2007. Using bullying incident density to evaluate the olweus bullying prevention progamme. School pyscologi internationl. 28 (2) . 234-245.

Chiu, I,s.(2013). Causes of Victims of Campus Bullying Behaviors and Study on Solutions. Journal of Social Sciences. 1 (2) : 13-22. DOI:10.4236/jss.2013.12003

Desiree .(2012). Bullying di pesantren. Jurnal Psikologi. FSIP_UI

Donoghue, A. \& Brandwein. (2014). Coping with verbal and social bullying in middle school. International Journal of Emotional Education, 4 (2): 2073-7629
Bagi tenaga kesehatan perlu meningkatkan upaya promotif dan preventif dengan kegiatan skrining agar dapat melakukan deteksi dini terkait masalah kesehatan jiwa pada remaja.

Herzt, F., \& Donato, I.(2013). Bullying and Suicide : public health approach. Journal of Adolescent Health. doi.101016.05.002.

Pollit, D. F., Beck, C. T \& Hungler, B. P. (2012). Nursing research: Generating and assesing evidence for nursing practice. (9ed). Philadelphia: Lippincot William \& Wilkins.

Kim, S., \& Yim, J,.(2015). Comparison between Physical Health and Mental Status of Korea High School Boarding Students. Journal of Depression and Anxiety. $s$ Anxiety.doi.org/10.4172/2167-1044.S1-009

Laeheem, K.(2013). Guidelines for solving bullying behaviors among islamic private school students in songkhla province. Asian Social Science, 9 doi:10.5539/ass.v9n11p83

Malian, M. (2012). Bully versus Bullied: A Qualitative Study of Students with Disabilities in Inclusive Settings. Electronic Journal for Inclusive Education. 10 (2).

Nakou \& Asimopoulus. (2014). Bullying in greek secondary schools: prevalence and 
profile of bullying practices. International Journal of Mental Health Promotion. doi :10.1007/s11218-012-9179-1

Ndetei, M., Ongecha, A., \& Khasakhala, L. (2007).Bullying In Public Secondary Schools In Nairobi, Kenya. Journal of Child and Adolescent Mental Health. 19(1): 45-55.

Omniyi, I. (2013). Bullying in schools: psychological implications and counselling interventions. Journal of Education and Practice, 4 (8): 2222-1735

Okoth, Joseph.(2014). Teachers' and students' perceptions on bullying Journal of Educational and Social ResearchBehaviour in Public, 4 (6).doi:10.5901/jesr.2014.v4n6p125

Rachel, A., \& Bernard, E,. (2014). Bulling in Graduate School: Its Nature and Effects. Journal Qualitative Report. 71 : 1-18

Sudan, A., S.(2015). School Bullying : Victimization In A Public Primary School In Selangor. Proceeding - Kuala Lumpur
International

Communication,

Education, Language and Social

Simbolon, M.(2012). Perilaku bullying pada mahasiswa berasrama. Jurnal Psikologi. 39 (2) : $233-243$

Salleh,M., N. \& Zainal, K.(2014). Bullying among secondary school students in malaysia: a case study. International Education Studies. doi:10.5539/ies.v7n13p184

Stuart, W,.Gail. (2016). Prinsip dan Praktik Keperawatan Kesehatan Jiwa. Edisi Indonesia Pertama. Singapura : Elseiver

Tumon, A.,B.(2014). Studi Diskriptif Perilaku Bullying pada Remaja. Jurnal Ilmiah Surabaya. 3 (1).

Wan ,S., Susan , M., \& Ruzyanei, N., (2009). School bullying amongst standard six students attendingprimary national schools in the Federal Territory of Kuala Lumpur: The prevalence and associated socio demographic factors. Malaysian Journal of $\begin{array}{lllll}\text { Psychiatry. } & 18 & \text { (1) : 250-259 }\end{array}$ 